\title{
Schools going mobile: A study of the adoption of mobile handheld technologies in Western Australian independent schools
}

\author{
Mark Pegrum, Grace Oakley and Robert Faulkner \\ The University of Western Australia, Australia
}

\begin{abstract}
This paper reports on the adoption of mobile handheld technologies in ten Western Australian independent schools, based on interviews with staff conducted in 2011. iPads were the most popular device, followed by iPod Touches and iPhones. Class sets were common at lower levels, with 1:1 models becoming increasingly common at higher levels. Mobile learning, or m-learning, was still at an experimental stage in most schools, but common themes were already emerging around the need to integrate mobile devices into a broader learning ecology. Key discussions focused on their role in promoting consumption or production, collaboration or personalisation, and creating seamless learning spaces. Used for both organisational and pedagogical purposes, mobile devices were seen as enhancing student motivation, with empirical evidence of improved student learning also emerging in small-scale studies conducted by two schools. Challenges included the need to carefully manage the technology, ethical issues in its use, and staff roles in its deployment. Pedagogically grounded and adequately contextualised professional development (PD) was seen as vital for time-poor staff, while a desire to set up a professional community of practice was widely expressed. All the schools surveyed planned to extend their use of mobile handheld technologies in the future.
\end{abstract}

\section{Introduction}

Information and communication technologies (ICTs) are taking on an ever greater prominence in education. Many governments are emphasising the need to turn out digitally literate, technologically able graduates who are employable in the global information economy (Buchanan, 2011). Many educators, by contrast, emphasise the creative, student-centred pedagogical approaches facilitated by digital tools, while others stress the role of online communication and collaboration in creating well-informed and wellconnected global citizens (Pegrum, 2009). Notwithstanding certain tensions between the goals of governments and those of educators, ICTs are becoming more and more enmeshed in teaching and learning.

In the Australian context, the Government's AUD \$2.4 billion Digital Education Revolution, linked to the new Australian Curriculum, is designed to promote the integration of ICTs in schools (DEEWR, 2011). Curriculum documents highlight the need for K-12 students to be taught how to use ICTs for a range of purposes. For example, both the Australian Curriculum in English (ACARA, n.d., a) and the Early Years Learning Framework (DEEWR, 2009) stipulate the need to teach young people how to understand and use digital texts as well as conventional printed texts. Further to this requirement, the Australian Curriculum includes ICT competence as a 'general capability'. Thus, students need to be taught how to use ICTs effectively across the curriculum, with specific requirements to investigate with ICTs, create with ICTs, communicate with ICTs, manage and operate ICTs, and use ICTs in socially and ethically appropriate ways (ACARA, n.d., b).

Mobile learning, or m-learning, is perhaps the fastest growth area in the whole field of ICTs in education. It covers any form of learning that is mediated through a mobile or, more precisely, mobile handheld, device. These devices encompass digital media players (including iPods and iPod Touches), smartphones (including iPhones, Android phones, BlackBerrys and Windows phones), personal digital assistants (PDAs), and tablet computers (including iPads). They are distinct from portable devices such as laptops which, although they can be transported to different locations, lack the convenience and flexibility of smaller handheld devices. To some extent, the growing prominence of mobile devices comes at the expense of more traditional portable devices as well as desktop devices, though it remains an open question as to whether mobile technologies are best seen as a replacement for, or a complement to, older technologies. 
The popularity of mobile handheld devices has increased dramatically in recent years. Mobile phone penetration stands at over $100 \%$ in most developed countries (Wansink et al., 2011), reflecting ownership of dual devices. In Australia, mobile phone penetration stood at over 130\% in mid-2012 (Buddhe, 2012), while smartphone penetration was $52 \%$ (Google \& Ipsos, 2012). Tablet penetration by household in Australia stood at $18 \%$ in early 2012 , with predictions it would reach $39 \%$ by the end of the year (IAB Australia, 2012).

At the start of 2011, the Horizon Report predicted that mobile devices would be widely adopted within education in the coming twelve months:

According to a recent report from mobile manufacturer Ericsson, studies show that by $2015,80 \%$ of people accessing the Internet will be doing so from mobile devices. Perhaps more important for education, Internet-capable mobile devices will outnumber computers within the next year. (Johnson, Smith, Willis, Levine, \& Haywood, 2011, p. 12).

In consequence, schools in Australia, as elsewhere around the world, have begun to investigate the affordances of mobile handheld technologies, particularly Apple devices such as the iPod Touch and the $\mathrm{iPad}$, for teaching a range of knowledge and skills across different areas of the curriculum. Because these technologies are a very new addition to classrooms, there is as yet little published research on which devices are being used at which levels; on how they are being integrated into different curriculum areas; on what benefits are being observed, what challenges are being faced, and how these are being addressed; and whether, on balance, mobile handheld devices are living up to their apparent promise. This study seeks to address this gap with a detailed investigation of current practices in Western Australian independent schools.

\section{Literature Review}

Given the limited research published to date on mobile handheld technologies in education, this literature review takes into account studies from around the world covering primary, secondary and tertiary levels. It also encompasses the more general theoretical literature, much of which is not specific with regard to educational levels.

\section{E-learning, m-learning and u-learning}

E-learning, or 'electronic learning' - which covers all learning through digital technologies - often depends primarily on fixed desktop devices. Interaction with such devices, as Traxler (2010) notes, "takes place in a bubble, and in dedicated times and places where the user has his or her back to the rest of the world for a substantial and probably premeditated episode" (p. 5). Although m-learning is often seen as a subset of e-learning, the fact that it depends primarily on mobile handheld devices makes it qualitatively different. By their nature, these devices lead to an expansion of the spaces and times of learning, with students learning outside the places of formal education and the hours of formal timetables (e.g., McCaffrey, 2011; Pachler, Bachmair, \& Cook, 2010; Seppälä \& Alamäki, 2003; Sharples, Taylor, \& Vavoula, 2010). An alternative term, u-learning, or 'ubiquitous learning' (Anderson, 2010; Bonk, 2009; Cope \& Kalantzis, 2009) has recently gained popularity. While the two terms cover much common ground (Hwang \& Tsai, 2011; Leone \& Leo, 2011), definitions are still evolving, with the latter term sometimes being used to suggest a higher level of contextual sensitivity and embeddedness (Leone \& Leo, 2011). It might be said that u-learning places less emphasis on mobility and contextual independence, and more emphasis on the situated, contextualised learning that mobile devices enable.

Many proponents of m-learning and u-learning favour a 1:1 model, i.e., where each student uses at least one personal device (e.g., Looi, Seow, Zhang, So, Chen, \& Wong, 2010). In some educational contexts, there is a push for a Bring Your Own Device (BYOD) or Bring Your Own Technology (BYOT) model, based on the idea that students should be encouraged to bring their personal devices, especially smartphones, to class (Kolb, 2008, 2011; Nielsen \& Webb, 2011; Richardson \& Mancabelli, 2011; cf. overviews and commentary in GSMA, 2011a, 2011b; Traxler, 2010) and to use them for learning across a range of formal and informal contexts. Typically, a BYOD model involves some institutional input on the range of permissible devices, whereas a BYOT model involves few limitations on the devices that can be 
used (Ferries-Rowe, 2012; Macgibbon \& Tarica, 2012). It is the capability to use devices across contexts that allows the creation of 'seamless learning spaces'. Challenging the traditional assumption of learning happening in fixed times and places, Looi et al. (2010) point out that:

with the diffusion of technology, the notions of place, time and space for learning have changed. The learning space is no longer defined by the 'class' but by 'learning' unconstrained by scheduled class hours or specific locations. With the mobile technologies at hand, students can learn seamlessly - both in classroom and out of classroom, both in school time and after school time. While learning can be facilitated or scaffolded by teachers or peers, at other times it could be student-initiated, impromptu and emergent. (pp. 156-157)

Mobile learners, as Pachler et al. (2010) explain, have to "operate successfully in, and across, new and ever changing contexts and learning spaces", which includes coming to understand "how to utilise our everyday life-worlds as learning spaces" (p. 6). In a sense, as they go on to point out, "the world has become the curriculum populated by mobile device users in a constant state of expectancy and contingency" (p. 25, with reference to Kress \& Pachler, 2007).

Rather than learning occurring "at the expense of real life" - with students sequestered away in clockgoverned classrooms, or chained to desktop technology - it can increasingly occur "as part of real life" (Traxler, 2010, p. 3). Significantly, when students learn with personal mobile devices embedded in their own personal contexts, there is much greater scope for individual customisation of education (McCaffrey, 2011; Melhuish \& Falloon, 2010; Pachler et al., 2010). In this way, m-learning and u-learning feed into broader educational trends towards the building of personal learning networks (PLNs), personal learning environments (PLEs) and e-portfolios (Oakley, Pegrum, \& Johnston, in press).

\section{From technologies to pedagogies}

The devices most commonly used in educational institutions fall into three main groups. Digital media players such as Apple's iPod (or the smaller iPod Shuffle) are compact devices which can play both audio and video. The iPod Touch, which evolved from the iPod, has been branded "a pocket computer" due to its ability to perform a variety of tasks (Banister, 2010, p. 122). With internet access, and now even the ability to send text messages, the latest iPod Touch - that is, the fourth generation iPod Touch running iOS5 software - differs from the iPhone mainly in its inability to make telephone calls.

Smartphones, including Apple's iPhone, Android phones, BlackBerrys and Windows phones, effectively combine a mobile phone, a digital media player, a digital audio recorder, a digital camera, a PDA, and a computer in one small device. Most importantly of all, they offer internet access, allowing users to download apps - that is, small pieces of specialised software typically obtained through an app store - as well as browse, seek information, and communicate online. A key advantage of smartphones is that many students already own these devices and carry them with them at all times, although to fully capitalise on this advantage an institution must have a BYOD/BYOT policy and teachers must be open to students using their smartphones in the classroom.

Tablets, including Apple's iPad, share many similarities with smartphones (though not the ability to make telephone calls) and laptops (though they typically work with apps rather than traditional software). They generally feature a touchscreen with an onscreen keyboard and/or a digital pen, alongside the ability to take photos and make audio and video recordings, all of which may be subsequently edited using appropriate apps downloaded from the internet. The educational appeal of tablets is emphasised in the 2011 K-12 Horizon Report:

While the idea of cell phones in the classroom too often conjures up images of disruption, tablets are a game-changer; they encompass many of the tools smartphones offer while presenting an ever-expanding collection of tools for learning. (Johnson, Adams, \& Haywood, 2011, p.15)

The iPad in particular is being widely adopted in educational settings around the world, though its use is still very much at an experimental stage. As a report of one university's experience puts it: 
With their students, [faculty] have become co-learners and pioneers in the classroom as they test out the power of this new technology. With no models to work from, they had to explore, practice, and discover - on their own - the iPad's potential for expanding learning. (Gawelek, Spataro, \& Komarny, 2011, p.32)

It will not escape notice that many of the devices most widely discussed in the literature are manufactured by Apple, a company which has been described as "poised to change the learning landscape" (GSMA, $2011 \mathrm{~b}$ ). It offers an integrated suite of stable, attractive and easy-to-use hardware and software, a constantly expanding number of third-party educational apps available through the iTunes Store, and strong support for educational ventures. While other mobile hardware and associated software is being trialled in educational institutions, Apple has emerged as the field leader.

In the broader field of e-learning, it has been recognised for some time that there is a danger of technology being overemphasised at the expense of pedagogy and content. A strong argument has been mounted that pedagogy and content should take precedence (Dudeney, Hockly, \& Pegrum, 2013; Motteram \& Ioannou-Georgiou, 2007; Pegrum, 2009) or at least be equally valued, as in the Technological Pedagogical and Content Knowledge (TPACK) teacher training model (Koehler, n.d.; Koehler \& Mishra, 2008). Commentators in the field of m-learning have, similarly, pointed out that what is important is not the technology per se (Melhuish \& Falloon, 2010; Pachler et al., 2010) but how it is used to support teaching and learning.

Like new technologies in general, mobile devices can support a range of pedagogical approaches, including traditional transmission and behaviourist approaches (e.g., Naismith, Lonsdale, Vavoula, \& Sharples, 2004). However, as in the broader field of e-learning (Pegrum, 2009), an emerging consensus suggests that mobile technologies - notably the iPad - are particularly suited to the promotion of social constructivism and related active, collaborative, student-centred approaches (e.g., Cochrane \& Bateman, 2010; Cochrane, Narayan, \& Oldfield, 2011; Kukulska-Hulme, Sharples, Milrad, Arnedillo-Sánchez, \& Vavoula, 2009; Looi et al., 2010; Melhuish \& Falloon, 2010).

\section{Experimenting with mobile handheld devices}

Around the world, and notably in the US, educators are exploring ways to use mobile technologies to enhance teaching and learning (Gagnon, 2010; GSMA, 2011a; Kolb, 2008, 2011). Mobile handheld devices have been used at all levels from primary to tertiary in a variety of curriculum and subject areas, including literacy, maths, social studies and science (for a list of K-12 studies, see Banister, 2010). Recent years have seen a dramatic increase in published research articles about m-learning and u-learning (Hwang \& Tsai, 2011), while more findings can be expected to emerge from numerous recent and current m-learning trials (e.g., GSMA, 2011a, 2011b).

In Australia, the 2011 iPads for Learning project in the State of Victoria, which distributed over 700 iPads to nine schools and one education institute, concluded that "quality of teaching, combined with purposeful and effective use of ICT contributes to improved learning" (DEECD, n.d.). In the tertiary sector, The University of Adelaide's Faculty of Sciences experimented with giving iPads to incoming first year students in 2011, and found that the devices greatly improved communication and opened up space for better teaching models (Herrick, 2011). In the same year, The University of Western Australia's Faculty of Education loaned iPads to all students in the first year of the Master of Teaching in Early Childhood and Primary programs, and concluded that the devices "contributed to pre-service teachers' learning, including their learning about teaching" (Pegrum, Howitt, \& Striepe, 2012). Meanwhile, under the National Vocational Education and Training (VET) E-learning Strategy, running from 2012-2015 (following on from the Australian Flexible Learning Framework of 2008-2011), funding has been released for emerging technology trials, including a focus on mobile technologies, apps, and app development (Commonwealth of Australia, n.d.).

As with the literature on e-learning in general, one of the strongest conclusions reached in the literature on m-learning is that it is motivating and engaging for students (e.g., Backer, 2010; Jones \& Issroff, 2007; Kukulska-Hulme \& de los Arcos, 2011; Pachler et al., 2010, pp. 66-67). Much of the research conducted to date is qualitative in nature, based on the perspectives and attitudes of educators and students, as 
established through case studies involving interviews, focus groups, open survey questions, journals and observations (e.g., Franklin \& Peng, 2008; Franklin, Sexton, Lu, \& Ma, 2007; cf. Hwang \& Tsai, 2011). Again, as with the broader e-learning literature, there are fewer quantitative studies which offer evidence of measurable improvements in student learning but there are a rising number of studies - sometimes on a modest scale, and sometimes with only weakly positive results - where such evidence is emerging. Recent controlled experiments demonstrating clear, statistically significant improvements in learning outcomes have been reported from areas as diverse as language learning (e.g., Hwang, Chen, \& Chen, 2011 [primary school, Taiwan]), maths (e.g., Cristol \& Gimbert, 2011 [primary and middle school, USA]), science (e.g., Ernst \& Harrison, 2011 [university, Australia]) and engineering (e.g., Enriquez, 2010 [community college, USA]), though it should be noted that these cover a wide variety of approaches to pedagogy and content as well as a wide variety of mobile devices. Nevertheless, they confirm the potential of m-learning not only to improve motivation but to improve learning outcomes on traditional assessments.

\section{Issues with mobile handheld devices}

The first point to remember with hardware is that, like new technologies in general, mobile devices were not designed for education but need to be repurposed for learning (Traxler, 2010). Certain physical features - such as, for example, small screen sizes on mobile phones (Chinnery, 2006; Cochrane, 2007; GSMA, 2011a, p. 23) - may present some challenges. Of more significance are broader design features. For example, the iPad 1 was seen by many as primarily a consumption tool rather than a productive or creative device (Kolowich, 2010), though the arrival of the iPad 2, with the addition of cameras and the availability of creative apps like iMovie and GarageBand, partly allayed this concern (Watters, 2011). Nevertheless, the iPad in all its iterations is still often viewed as a supplement - even a "luxury supplement" (Smith cited in Kolowich, 2010) - rather than a replacement for desktop and/or laptop devices (Jennings, Anderson, Dorset, \& Mitchell, 2010), especially at higher levels of education. Of course, if specific devices carry specific limitations, then a BYOD/BYOT model presents challenges of a different kind in terms of the standards and specifications of the devices permitted to be used in class and, in particular, to log into an institution's network, with all of the attendant implications for institutional policies as well as IT support (Traxler, 2010). In this context, network speed and capacity, as well as network security, are likely to become ever more important issues (e.g., Cochrane, 2007; Melhuish \& Falloon, 2010; Traxler, 2010).

Software is also a key issue. Concerns over the spread of 'non-generative' devices under the control of a single company are not new (Zittrain, 2008), but they have intensified with the shift to the locked down, app-driven environments of smartphones and tablets, with the strongest critique generally reserved for Apple's stringent controls and insistence on pre-approving all apps (Chen, 2011; Gillmor, 2010; Hirschorn, 2010; MacKinnon, 2012; Melhuish \& Falloon, 2010; Zittrain, 2010). Moreover, despite the number of apps available, teachers find that many have limited educational value because they are underpinned by information transmission or behaviourist drill-and-practice approaches (Murray \& Olcese, 2011) and, therefore, provide only a limited supplement to social constructivist classrooms oriented towards problem solving and critical enquiry. On the other hand, as noted above, more creative apps are now beginning to emerge, and still more can be expected to appear as research in this area progresses.

Many commentators have remarked on the need for adequate technical support (e.g., Cochrane, 2007; Franklin \& Peng, 2008). However, it is noted in some recent literature that a number of students are developing considerable relevant expertise, on which less tech-savvy students and even teachers can draw (McCaffrey, 2011; cf. Dudeney et al., 2013; Richardson \& Mancabelli, 2011). iPads have been identified by some as intuitive tools which require less support (e.g., Redington Bennett, 2011/12).

Teaching in distributed, personalised mobile environments presents certain challenges. Theorists of digital literacies have noted that mobile literacy, far from being a naturally acquired skillset, may require explicit development $(\mathrm{Ng}, 2011$; Parry, 2011). Students must learn to navigate, interpret information from, contribute information to, and communicate through the mobile web, mobile apps and the 'mixed reality' they engender, where the real and the virtual are interlinked (Dudeney et al., 2013). In an intensification of an issue that exists to some extent in all networked learning contexts (Pegrum, 2010), it may be problematic for teachers to create stable spaces within this fluid mobile environment in order to 
guide, capture and document learning (Melhuish \& Falloon, 2010; Sharples et al., 2010). Moreover, as with most e-learning, traditional forms of assessment may not lend themselves easily to m-learning (Melhuish \& Falloon, 2010; Traxler, 2010).

Again, as in the broader field of e-learning, appropriate teacher training is vital to ensuring that mobile devices are used in pedagogically sound ways (Melhuish \& Falloon, 2010). Teachers need to develop a critical awareness of the range of pedagogical approaches to which m-learning lends itself, and actively balance considerations of pedagogy and content with considerations of technology, as per the aforementioned TPACK model. Once they have acquired a sufficient knowledge base, teachers must be ready to engage in self-directed learning as technologies change, their teaching contexts shift, and their students' needs evolve; in short, teacher training must ultimately be about "helping teachers to help themselves" (Robb, 2006). This might well include encouraging them to tap into professional communities of practice (Hanson-Smith, 2006) and/or professional learning networks (Dudeney et al., 2013) for ongoing learning.

There are longstanding discussions of equity and access issues in e-learning. Many of these refer to a 'digital divide', not only in terms of student access to hardware and software, but in terms of the development of the digital skills linked to such access (Dudeney et al., 2013; Pegrum, 2009). A BYOD/BYOT model of m-learning, in particular, may exacerbate such concerns. Other ethical issues arise around digital safety, privacy and surveillance, and the blurring of public/private boundaries (e.g., Pachler et al., 2010; Traxler, 2010). All of these are well-known challenges in the field of e-learning, but present even greater difficulties when mobile rather than fixed devices are involved.

\section{Aims \& Methodology}

This article reports on the findings of the first phase of a project entitled Exploring the Pedagogical Applications of Mobile Technologies for Teaching Literacy, funded by the Association of Independent Schools of Western Australia (AISWA). Anecdotal evidence suggested that a number of schools in Western Australia were starting to 'go mobile', but no comprehensive overview was available. Phase 1 of the research, reported here, was designed to establish such an overview of current practices and to draw out any key lessons and insights which might be shared across the sector. This led to two sets of professional development (PD) workshops, for K-6 and 7-12 teachers respectively, to disseminate the initial results of the first phase and to begin building a community of practice, centred around the purpose-built MLearnWA wiki (mlearnwa.wikispaces.com), for the sharing of understandings. The primary focus on literacy reflected the expertise of the research team and helped circumscribe the project, ensuring that it was manageable in a short time frame. In Phase 2, not reported here as it is still ongoing, case studies have been conducted in three of the Phase 1 schools, as well as three further schools which have recently introduced mobile handheld technologies. We have been able to share insights gained in Phase 1 with the latter three schools, as well as encouraging them to integrate into the wider MLearnWA community. The MLearnWA wiki has now been opened up to broader membership.

In Phase 1, we worked within an interpretivist paradigm as we sought participants' views on how mobile technologies were or could be used. To begin with, a general invitation was issued to all AISWA school principals, asking them to identify key staff in their institutions who were using mobile technologies and were willing to participate in a semi-structured interview. Interviewees included principals, vice principals, technology co-ordinators and teachers in a total of ten institutions - eight in metropolitan Perth, one around fifty (50) $\mathrm{km}$ from the city centre, and one in a regional city around two hundred (200) $\mathrm{km}$ from Perth. In the majority of cases, senior management and teaching staff were able to offer an overview of technology use at all schooling levels, from early childhood and primary through to middle and upper school. Their views were complemented by those of a range of teachers from across these levels who volunteered to participate in the interviews. Interviews were loosely structured around the following set of questions: 
- How do you use mobile handheld technologies, particularly for teaching literacy?

- Why do you use them this way?

- What benefits to the students' learning have you observed?

- What problems, if any, have you encountered?

- What professional development do you think is needed by the teachers at your school?

- Would you be interested in helping develop/deliver some professional development?

While our initial focus was on literacy, including multimedia literacy, it became apparent that schools were using mobile devices for a range of other purposes, both pedagogical and organisational, and interviewees were invited to give details of these. Our original supposition, based on anecdotal evidence, that iPod Touches and iPads would be the preferred devices proved to be correct, but interviewees were also invited to comment on any other mobile technologies being used. The final question was designed to lead into a discussion of the planning of the second set of professional development workshops which took place towards the end of Phase 1 .

Interviews took place in Terms 3 and 4, 2011. All were face-to-face, with the exception of the regional interview which was conducted by telephone, and all were digitally recorded. A research assistant made detailed notes, accompanied by transcriptions of key passages, which were checked for accuracy firstly by the interviewers and subsequently by the interviewees. Minor alterations were made to a number of sets of notes and transcriptions. The data were then analysed in an inductive process using methods drawn from grounded theory (Glaser \& Strauss, 1968). The research assistant conducted open coding of the final texts (Corbin \& Strauss, 2008). This was confirmed by the researchers, who then independently carried out theoretical coding. Finally, key principles were distilled from the theoretical coding in a collaborative meeting between the researchers and the research assistant.

In the following discussion, schools are identified by letters (A-J) only. Because of the easy identifiability of schools within Western Australia, demographic and other descriptive data are not included. However, the ten schools in our sample are all fee-paying institutions, with a range of fee schedules, which are among the one hundred and sixty-five (165) AISWA member schools.

\section{Findings}

The mobile handheld device most commonly mentioned by interviewees was the iPad, which was already used, or was about to be introduced, in all ten schools. It was followed by the iPod Touch, used in four schools, though some interviewees regarded the latter as "redundant" (School C) and less "usable" (School D) than the iPad. Despite the high rate of smartphone penetration in Australia, just two schools permitted the use of iPhones in the classroom under the direction of teachers, one from Year 7 (middle school) onwards and one from Year 11 (upper school) onwards. Some other schools permitted students to bring smartphones for private use outside the classroom. The only non-Apple device mentioned by name in the interviews was a Toshiba tablet, used at one school that was, however, about to transition to Apple products. A number of schools used laptops, with the MacBook Air and MacBook Pro being mentioned, but these devices fell outside the scope of our project's focus on mobile handheld technologies. Only one interviewee, who expressed a personal preference for Android devices, picked up on the concern commonly expressed in the literature about users becoming locked into a controlled technological environment under the management of a single corporation.

Most schools were using the iPad 2, though some still had the older iPad 1 available. Echoing the published literature, the iPad was viewed as very easy to use: without the need for booting up time or logging in, and with its intuitive design, it was felt that it required less student support. It was seen as especially appropriate for early childhood education, largely due to its tactile interface which was more accessible to children than a mouse: "they took to it straight away ... we underestimated that", as one interviewee put it (School I). The table below shows the usage of iPads across school levels. While interviewees were encouraged to describe all uses of iPads and other mobile handheld technologies in their schools, it is possible that not every case was mentioned. Nevertheless, the table provides a snapshot of emerging trends. It is clear that iPads are most popular at early childhood and primary levels, with class sets the norm until middle and upper school, at which point some institutions shift to a 1:1 model. 
Table 1

iPad Usage Models

\begin{tabular}{|c|c|c|c|c|}
\hline & $\begin{array}{l}\text { Early Childhood } \\
\text { (Years K-2) }\end{array}$ & $\begin{array}{l}\text { Primary School } \\
\text { (Years 3-6) }\end{array}$ & $\begin{array}{l}\text { Middle School } \\
\text { (Years 7-9) }\end{array}$ & $\begin{array}{l}\text { Upper School } \\
\text { (Years 10-12) }\end{array}$ \\
\hline Class Set & & $-A--B--C$ & $-B-C-$ & $-B-C--D--I-$ \\
\hline 1:1 Model & & $-D-$ & $-\mathbf{A}-\mathrm{-G}-\mathrm{-J}-$ & $-A-D-$ \\
\hline
\end{tabular}

Note. This table shows current and proposed iPad usage models by schools (A-J) across levels at the end of 2011.

Broad issues relating to our first two interview questions, about how mobile technologies were being used in schools, will be covered in the first section below; views on the benefits and drawbacks of m-learning, relating to our third and fourth questions, in the second section; and views on professional development, relating to our final two questions, in the third section.

\section{An ecology of learning}

Most schools were still at the stage of actively experimenting with mobile handheld technologies, especially iPads, trialling their use at different levels and for different purposes. It quickly became apparent that many principals, vice principals and teachers had reached the same conclusion as the theorists of m-learning, namely, that the devices themselves are less important than how they are used to support teaching and learning. It was stressed that these technologies should not be seen as an end in themselves, nor as an add-on to entertain children and keep them busy: "we do not use technology as a babysitting device", said one participant (School F). Rather, schools were investigating the best ways of "fully integrating" (School D) mobile devices into an overall ecology of learning. Several interviewees explicitly insisted that good teaching and teachers had to remain the main drivers, while others spoke of the need to "marry up" the devices with the curriculum (School C) or the need to strike a sensible balance between new technologies and old technologies like pens and paper, a particular concern for young children developing fine motor skills (Schools C \& F). On the other hand, at least two interviewees closely mirrored the consensus in the m-learning literature that mobile devices can help in the shift from a sage-on-the-stage pedagogical model to a more collaborative, student-centred model (Schools A \& F). Two others also commented that using mobile devices could help them fulfil the new Australian Curriculum's requirement for ICTs to be embedded in all curriculum areas (Schools F \& J). At the same time, again echoing the m-learning literature, one interviewee spoke at length of the mismatch between traditional assessments like the Tertiary Entrance Examination on the one hand, and the collaborative and communicative skills students gain through using new technologies on the other. He saw a danger that these devices might therefore be seen as a "distractor" at senior levels in particular (School A). Indeed, this might be one reason why such technologies seem more appropriate at lower levels, where there is more freedom to experiment. Two interviewees commented explicitly on the play-based learning that mobile devices could foster at early childhood level (Schools H \& I).

Another key reason for using mobile devices at lower levels relates to their role as consumption vs production devices. Interviewees shared the concerns expressed in the literature that many apps are pedagogically limited, and considered them best suited to reinforcing elements of learning (such as letter formation or spelling) at early childhood and primary levels. A number of interviewees commented that the arrival of "generic apps" (Schools A \& D) such as GarageBand and iMovie had opened up the possibilities for students to be more creative as well as sharing and publishing their work, showcasing it to peers and parents (see below for more details). However, the general feeling was that as students advanced, they would need more generative devices instead of, or in addition to, devices like iPads. Two schools used laptops in a 1:2 ratio from Year 1 onwards, changing to a 1:1 ratio in Year 5; another used 
notebooks from Year 4. Where iPads were being used - or proposed for use - at middle and/or upper levels, there was generally a clear expectation that students would use them in conjunction with personal laptop or desktop devices. As one interviewee pointed out, iPads, with their ability to store large numbers of e-books, might be seen as an alternative to books rather than computers at higher levels (School D). As three interviewees indicated, however, this may be premature, as only a limited selection of e-textbooks is currently available (Schools A, D \& J).

The issue of collaboration vs personalisation produced certain tensions in the m-learning trials. Using class sets makes collaboration inevitable: several interviewees felt this was appropriate at early childhood and primary levels, with students learning important skills of sharing and teamwork while interacting around these devices in pairs or small groups (Schools D, H \& I). However, at least one individual recognised the friction between the single-owner design of iPads and their use in class sets: "we are doing something that is alien to the device ... we have tried to make it behave like a laptop in a trolley when it really should be a student-owned device" (School B). Where these devices were being used at middle school or upper school levels, participants tended to emphasise their personalised nature. A parentfunded, 1:1 model was being considered by one school, while it was being instituted in another, with iPads the mandated tools in both cases. In one school, students were advised to buy iPads but were given the option of purchasing a MacBook instead, if they so preferred. Two schools had more flexible versions of a BYOD model, where students were able to use their own iPhones instead of, or in addition to, iPod Touches and/or iPads.

Some schools were beginning to capitalise on the seamless learning spaces opened up by mobile devices. Because they are easy even for small children to carry, such devices extend traditional learning spaces: "Being so mobile, you are not restricted to being in your classroom or at desks" (School I). It was noted that students had more flexibility in when and how to learn, opting, for example, to work on their iPads outside the classroom during lunch breaks (School A). One school, responding to this newfound freedom, was setting up flexible classrooms with no fixed desks in order to foster collaboration and communication between students - a change which some teachers were finding challenging (School G). It was observed by the researchers that a number of schools with more longstanding laptop programs already had such flexible arrangements in place.

It became clear that mobile handheld technologies have both organisational and pedagogical purposes. In some institutions, they served as important means of communication between staff and students (School A) or a way of disseminating information to teachers, students and parents (School E). Mobile devices could help students stay organised through the use of diary apps and push notifications like homework reminders (School A). Pedagogical uses included employing apps relevant to areas as diverse as numeracy (mentioned by 7 schools), maths (4), science (2), foreign languages (1) and accounting and economics (1). Our particular focus on literacy, unsurprisingly, led interviewees from all ten schools to mention apps appropriate to this area. At least three schools were using apps to help children practise letter formation and word writing, while many schools used interactive e-books for children. As noted above, there was some concern about the pedagogically limited nature of many apps. Creative apps which allowed students to tell their own stories, generally in multimedia formats, were highly valued: Comic Life and Puppet Pals, for example, were popular at lower levels, with iMovie and GarageBand popular at higher levels. The rest of the suite of Apple's productive apps, like Pages, Numbers and Keynote, were used across all levels but particularly in middle and upper school. These "generic apps" were seen as crucial to teachers' ability to use mobile devices in more constructivist, student-centred ways, notwithstanding the fact that, as indicated earlier, many schools opted to use laptops in addition to or in place of mobile handheld devices, especially at higher levels.

\section{Benefits and drawbacks of m-learning}

As in the m-learning literature, the most commonly mentioned benefit of mobile handheld devices was the level of motivation and engagement for students, a point on which the majority of interviewees touched but which was most noted at lower levels. The students' faces "light up" when the iPads are brought out, said one interviewee about primary classes (School B). It was also noted that the devices were motivating for some, if not all, of the staff, many of whom had put a lot of time and energy into integrating them into their lessons; as one interviewee put it: "They've been so enthusiastic about it. Lots 
of teachers that you wouldn't necessarily think would be on board with technology [have] really got on board with it" (School D).

The place of mobile devices in fulfilling the ICT requirements of the Australian Curriculum has already been noted above, as has their broader value in teaching new collaboration and communication skills. Two schools had conducted informal, small-scale empirical studies, which revealed improved learning outcomes on traditional assessments. School B compared the ability of Year 3 students to retain French vocabulary across three classes, including a control group, and found that the students who had used the iPads and the relevant vocabulary apps recalled between 20 and 26 words as opposed to the expected 12, as recalled by the control group. School D tested Year 4 students on mental maths at the beginning and end of a term-long 1:1 iPad program and found an improvement, which teachers attributed to the immediate feedback provided by the relevant apps. Explaining his school's decision to expand its iPad program, the interviewee from School B put it this way:

We have answered those questions [about the benefits] with the first initial pilot; yes, there is engagement there; yes, the kids are getting on task a little bit quicker; and yes, we can see that they are retaining that knowledge when we do the assessment at the end.

It was also pointed out by three schools $(C, D \& G)$ that there are particular benefits for students with special needs, including students who require early intervention or are struggling with the curriculum, and students with visual impairments or dyslexia, who can resize and reformat text as well as using voice recognition and text-to-speech apps.

Drawbacks of mobile handheld devices include hardware issues (such as the small screen size, especially on iPod Touches, a point mentioned by Schools F and I), software issues (the need to sync apps across multiple devices, mentioned by several schools, as well as uncertainty about how to do this legally - a situation which should now be clearer due to Apple's launch of its Volume Purchase Program [VPP] in Australia in 2012) and network issues (especially outside the metropolitan area, where the internet is noticeably slower). It was noted that there had to be enough devices available in class sets, and three schools stressed the importance of staff having their own devices to work from, ideally with some lead-in time to build familiarity with the technology before using it in the classroom (Schools A, G \& J). IT issues were flagged up by one interviewee, who suggested that teachers' organisational and pedagogical freedom was being restricted by IT security policies. While none of the schools reported that any serious digital safety or security incidents had occurred to date, ethical issues were being pre-emptively considered. Many schools had chosen Wi-Fi-only iPads to make it more difficult for students to use 3G networks to bypass school content filters. Several schools had set out very explicit student guidelines, for example banning audio or video recordings being made without the permission of teachers or other students (School A), while a number were conducting or planning to conduct information sessions for parents, covering, amongst other things, digital safety and cyberbullying.

Across the board, staff issues were flagged up as crucial: "the staff is the biggest blocker", said one interviewee. Four interviewees indicated that at least some staff in their institutions were unenthusiastic, while other highlighted issues included the fact that some teachers felt overwhelmed and underprepared; that some were unsure how to integrate mobile devices with their teaching, or did so in pedagogically limited ways; and, most importantly of all, that all were time-poor, which limited their availability for PD as well as the time they had to spend researching the most appropriate apps (with the latter point being explicitly mentioned by six schools). Such issues fed into a consideration of PD needs.

\section{Professional development needs}

It was reported that teachers had displayed a wide spectrum of responses to mobile handheld technologies - from enthusiastic to disinterested or, in rare instances, opposed - but many schools were taking "a soft approach" (School A) and not forcing staff to participate in m-learning initiatives against their will. Where participation was required, schools were careful to proceed slowly, offering PD and mentoring with the aim of "setting [teachers] up for success" (School F). Nevertheless, in a context of rapidly evolving mobile devices and time-poor teachers, the introduction of new technologies into the classroom inevitably produces tensions. Across the ten interviews, four main recommendations emerged regarding PD. These recommendations can helpfully inform policy decisions about PD needs made by institutions 
which, having decided to introduce mobile technologies, are seeking ways to facilitate their smooth and effective integration into the school learning ecology:

1. Bracketed time for $P D$ is necessary to support the pedagogically grounded rollout of new technologies. Staff need time to attend formal PD; engage in informal collaborations with colleagues; play with devices in order to build familiarity; research apps; and explore wider pedagogical possibilities. At least one school was squeezing in PD at 7.30 in the morning, with breakfast provided!

2. A focus on pedagogy ahead of technology in $P D$ is essential. Interviewees remarked that teachers needed help integrating new tools in a pedagogically sound manner (School D), including encouragement to move beyond pedagogically limited apps (School C) and to explore truly innovative uses of the devices (School B). One interviewee remarked that it was already the case in his school that "pedagogy and practice drive our PD more than tools and applications" (School E), while another flagged up a need to move in this direction, suggesting that it would be valuable "to have a session on teaching theory and to reflect on [teachers'] practice, to help to justify their approach to teaching, and to help broaden their practice" (School I).

3. Targeted and contextualised PD is most effective. In a rapidly changing field, formal PD cannot cover all possibilities. Moreover, for time-poor teachers, standardised PD sessions are likely to be less effective than individualised PD delivered at the point of need, for example, support being provided by a technology co-ordinator or mentor in the classroom to a teacher creating a particular kind of lesson for a particular cohort. Schools A and D were already working with this model, with School $\mathrm{G}$ planning to move in this direction.

4. Building a professional community of practice/professional development network as a platform for $P D$ is a sustainable model which could encourage collaboration, save time and energy, and avoid schools and teachers 'reinventing the wheel'. Several interviewees praised the State of Victoria's support of iPads in the classroom (DEECD, n.d.) and expressed a desire for a Western Australian educators' network, ideally with an accompanying online hub. Such a community or network would of course provide a base for "helping teachers to help themselves", as Robb (2006) was seen to suggest earlier. One interviewee spoke of fostering "a more collaborative teacher culture" (School A) and another of the value of being able to "tap into a community of support" (School B). In particular, interviewees were keen to find out what other schools were doing (Schools C, D \& H), and many expressed a wish to exchange information about useful apps, how they map to the Australian Curriculum, and which ones might be of particular relevance to the Western Australian context. The MLearnWA wiki, mentioned above, provides a platform for this kind of network building.

\section{Conclusion}

The use of mobile handheld technologies is still at an experimental stage in Western Australian independent schools, but it is set to expand dramatically in coming years. Although the current study is limited by its small, opportunistic sample, it provides an early snapshot of a developing field where there is currently little more than anecdotal evidence available. Surprisingly clear common themes have in fact emerged even from this small sample, many of them providing a practical slant on theoretical understandings drawn from the m-learning literature, or providing a local slant on results of national and international m-learning trials. These include insights regarding the levels and purposes for which devices such as iPads and iPod Touches are best used; their benefits for motivation and learning outcomes, and the potential drawbacks connected to the technology itself as well as ethical issues and staff issues; and the need for appropriate professional development opportunities for teachers.

Many interviewees expressed considerable interest in what other interviewees had told us, since they were, for the most part, experimenting in isolation from each other. The desire for PD on how best to integrate m-learning with the curriculum and pedagogy was perhaps the single strongest point to emerge from the interviews. It is hoped that the community of practice established towards the end of the first phase - with the help of several of our interviewees, who willingly contributed to the second set of PD workshops - will serve to connect these principals, vice principals, technology co-ordinators and teachers 
with each other, notably via the MLearnWA wiki. It is also hoped that, as more schools venture down the road of m-learning, they too will integrate into and enrich the existing community, which was opened up to a wider membership base during the second phase of the research. Following the conclusion of the second phase, we anticipate publishing a follow-up paper based on a series of case studies and offering more specific conclusions and recommendations with regard to professional development in the evolving area of m-learning.

\section{Acknowledgements}

We are grateful to AISWA for funding the research underpinning this project; to Jan Clarke, ICT Integration Consultant at AISWA, for her support of the project and organisation of the PD workshops; to Helen House, for her efficient project management; to Adam Marchant and Jeannine Wishart for their support with interviews; and to Michelle Striepe, for her help in data collection and analysis.

\section{References}

ACARA [Australian Curriculum, Assessment and Reporting Authority]. (n.d., a). The Australian Curriculum: English (Rationale/Aims). Retrieved from http://www.australiancurriculum.edu.au/English/Rationale

ACARA [Australian Curriculum, Assessment and Reporting Authority]. (n.d., b). The Australian Curriculum: Information and communication technology (ICT) capability (Organising elements). Retrieved from http://www.australiancurriculum.edu.au/GeneralCapabilities/Information-andCommunication-Technology-capability/Organising-elements/Organising-elements

Anderson, J. (2010). ICT transforming education: A regional guide. Bangkok: UNESCO. Retrieved from http://unesdoc.unesco.org/images/0018/001892/189216e.pdf

Backer, E. (2010). Using smartphones and Facebook in a major assessment: The student experience. EJournal of Business Education \& Scholarship of Teaching, 4(1), 19-31. Retrieved from http://www.ejbest.org/upload/eJBEST_Backer_2010_4(1).pdf

Banister, S. (2010). Integrating the iPod touch in K-12 education: Visions and vices. Computers in the Schools, 27(2), 121-131. Retrieved from http://dx.doi.org/10.1080/07380561003801590

Bonk, C. J. (2009). The world is open: How web technology is revolutionizing education. San Francisco, CA: Jossey-Bass.

Buchanan, R. (2011). Paradox, promise and public pedagogy: Implications of the Federal Government's Digital Education Revolution. Australian Journal of Teacher Education, 36(2), 67-78. Retrieved from http://ro.ecu.edu.au/cgi/viewcontent.cgi?article=1524\&context=ajte

Buddhe, C. (2012). Australia - Mobile communications - Subscriber statistics. BuddheComm. Retrieved from http://www.budde.com.au/Research/Australia-Mobile-Communications-SubscriberStatistics.html

Chen, B. X. (2011). Always on: How the iPhone unlocked the anything-anytime-anywhere future-and locked us in. Cambridge, MA: Da Capo.

Chinnery, G. M. (2006). Going to the MALL: Mobile assisted language learning. Language Learning \& Technology, 10(1), 9-16. Retrieved from http://lt.msu.edu/vol10num1/pdf/emerging.pdf

Cochrane, T. (2007). Mobile web2 pedagogies. In D. Parsons \& H. Ryu (Eds.), Proceedings of the Conference on Mobile Learning Technologies and Applications (MoLTA) 2007, Massey University, Auckland, New Zealand (pp. 31-38). Retrieved from http://molta.massey.ac.nz/massey/fms//Molta/Cochrane.pdf

Cochrane, T., \& Bateman, R. (2010). Smartphones give you wings: Pedagogical affordances of mobile web 2.0. Australasian Journal of Educational Technology, 26(1), 1-14. Retrieved from http://www.ascilite.org.au/ajet/ajet26/cochrane.pdf

Cochrane, T., Narayan, V., \& Oldfield, J. (2011). iPadagogy: Appropriating the iPad within pedagogical contexts. In 10th World Conference on Mobile and Contextual Learning, 18-21 October 2011, 
Beijing, China: mLearn2011 Conference Proceedings (pp. 146-154). Beijing: Beijing Normal University. Retrieved from http://mlearn.bnu.edu.cn/source/Conference_Procedings.pdf

Commonwealth of Australia. (n.d.). National VET E-learning Strategy. Retrieved from http://www.flexiblelearning.net.au/

Cope, B., \& Kalantzis, M. (Eds.). (2009). Ubiquitous learning. Urbana, IL: University of Illinois Press.

Corbin, J., \& Strauss, A. (2008). Basics of qualitative research: Techniques and procedures for developing grounded theory (3rd ed.). Thousand Oaks, CA: Sage.

Cristol, D. \& Gimbert, B. (2011). Accessing mathematics through mobile learning devices for students with learning difficulties. In $10^{\text {th }}$ World Conference on Mobile and Contextual Learning, 18-21 October 2011, Beijing, China: mLearn2011 Conference Proceedings (pp. 321-327). Beijing: Beijing Normal University. Retrieved from http://mlearn.bnu.edu.cn/source/Conference_Procedings.pdf

DEECD [Department of Education and Early Childhood Development], Victoria, Australia. (n.d.). iPads for learning: iPad trial (Evaluation). Retrieved from http://www.ipadsforeducation.vic.edu.au/ipadstudent-trial/ipad-research

DEEWR [Department of Education, Employment and Workplace Relations]. (2009). Belonging, being and becoming: The Early Years Learning Framework for Australia. Canberra, ACT: Commonwealth of Australia. Retrieved from http://www.deewr.gov.au/Earlychildhood/Policy_Agenda/Quality/Documents/Final\%20EYLF\%20Fra mework\%20Report\%20-\%20WEB.pdf

DEEWR [Department of Education, Employment and Workplace Relations]. (2011). Digital education revolution. Canberra, ACT: Commonwealth of Australia. Retrieved from http://www.deewr.gov.au/Schooling/DigitalEducationRevolution/Pages/default.aspx

Dudeney, G., Hockly, N., \& Pegrum, M. (2013). Digital literacies. Harlow: Pearson.

Enriquez, A. G. (2010). Enhancing student performance using tablet computers. College Teaching, 58(3), $77-84$.

Ernst, H., \& Harrison, J. (2011). The use of mobile learning to develop understanding of biomedical sciences. In $10^{\text {th }}$ World Conference on Mobile and Contextual Learning, 18-21 October 2011, Beijing, China: mLearn2011 Conference Proceedings (pp. 66-69). Beijing: Beijing Normal University. Retrieved from http://mlearn.bnu.edu.cn/source/Conference_Procedings.pdf

Ferries-Rowe, J. D. (2012, March 29). Choosing between BYOT and BYOD: Why one letter might make a difference. Confessions of a Jesuit School CIO. Retrieved from http://geekreflection.blogspot.com.au/2012/03/choosing-between-byot-and-byod-why-one.html

Franklin, T., \& Peng, L.-W. (2008). Mobile math: Math educators and students engage in mobile learning. Journal of Computing in Higher Education, 20, 69-80.

Franklin, T., Sexton, C., Lu, Y., \& Ma, H. (2007). PDAs in teacher education: A case study examining mobile technology integration. Journal of Technology and Teacher Education, 15(1), 39-57.

Gagnon, D. J. (2010). Mobile learning environments. EDUCAUSE Quarterly, 33(3). Retrieved from http://www.educause.edu/EDUCAUSE+Quarterly/EDUCAUSEQuarterlyMagazineVolum/MobileLea rningEnvironments $/ 213690$

Gawelek, M. A., Spataro, M., \& Komarny, P. (2011). Mobile perspectives: On iPads. Why mobile? EDUCAUSE Review, 46(2), 28-32. Retrieved from http://net.educause.edu/ir/library/pdf/ERM1123.pdf

Gillmor, D. (2010). Mediactive. Raleigh, NC: Lulu.

Glaser, B. G., \& Strauss, A. L. (1968). The discovery of grounded theory: Strategies for qualitative research. London: Weidenfeld \& Nicolson.

Google \& Ipsos (2012, May). Our mobile planet: Australia. Understanding the mobile consumer. Retrieved from http://services.google.com/fh/files/blogs/our_mobile_planet_australia_en.pdf 
GSMA. (2011a). Mobile education in the United States. London: GSMA. Retrieved from http://www.gsmaembeddedmobile.com/upload/resources/files/USA_11_08_11_interactive1.pdf

GSMA. (2011b). Mobile education landscape report. GSMA: London. Retrieved from http://www.gsmaembeddedmobile.com/upload/resources/files/Landscape_11_08_11_interactive.pdf

Hanson-Smith, E. (2006). Communities of practice for pre- and in-service teacher education. In P. Hubbard \& M. Levy (Eds.), Teacher education in CALL (pp. 300-315). Amsterdam: John Benjamins.

Herrick, C. (2011, October 14). iPads have reduced costs, improved communication for Uni of Adelaide. Computerworld. Retrieved from

http://www.computerworld.com.au/article/404175/ipads_reduced_costs_improved_communication_u ni adelaide/

Hirschorn, M. (2010, July-August). Closing the digital frontier. The Atlantic. Retrieved from http://www.theatlantic.com/magazine/archive/2010/07/closing-the-digital-frontier/8131/1/

Hwang, G.-J., \& Tsai, C.-C. (2011). Research trends in mobile and ubiquitous learning: A review of publications in selected journals from 2001-2010. British Journal of Educational Technology, 42(4), E65-E70.

Hwang, W.-Y., Chen, C.-Y., \& Chen, H. S. L. (2011). Facilitating EFL writing of elementary school students in familiar situated contexts with mobile devices. In $10^{\text {th }}$ World Conference on Mobile and Contextual Learning, 18-21 October 2011, Beijing, China: mLearn2011 Conference Proceedings (pp. 15-23). Beijing: Beijing Normal University. Retrieved from http://mlearn.bnu.edu.cn/source/Conference_Procedings.pdf

IAB [Interactive Advertising Bureau] Australia. (2012,March 5). Nielsen Australian online consumer report 2011-2012 [Media release]. IAB Australia. Retrieved from

http://www.iabaustralia.com.au/index.php?/news/story/nielsen_australian_online_consumer_report_2 011-201202

Jennings, G., Anderson, T., Dorset, M., \& Mitchell, J. (2010). Report on the Step Forward iPad Pilot Project. Melbourne: Trinity College, University of Melbourne. Retrieved from https://docs.google.com/viewer?a=v\&pid=explorer\&chrome=true\&srcid=0B5lvGCuvwcgXZWZkYm EzNDMtNmQ1OS00NmRhLTlhYmItOTU5NmVhYWJINDA1\&hl=en\&pli=1

Johnson, L., Adams, S., \& Haywood, K. (2011). The NMC Horizon Report: 2011 K-12 Edition. Austin, TX: The New Media Consortium. Retrieved from http://media.nmc.org/iTunesU/HR-K12/2011/2011Horizon-Report-K12.pdf

Johnson, L., Smith, R., Willis, H., Levine, A., \& Haywood, K. (2011). The 2011 Horizon Report. Austin, TX: The New Media Consortium. Retrieved from http://net.educause.edu/ir/library/pdf/HR2011.pdf

Jones, A., \& Issroff, K. (2007). Motivation and mobile devices: Exploring the role of appropriation and coping strategies. Research in Learning Technology, 15(3), 247-258.

Koehler, M. J. (n.d.). TPACK - Technological pedagogical and content knowledge. Retrieved from http://www.tpck.org/

Koehler, M. J., \& Mishra, P. (2008). Introducing TPCK. In AACTE Committee on Innovation and Technology (Ed.), Handbook of technological pedagogical content knowledge (TPCK) for educators (pp. 3-29). New York: Routledge.

Kolb, L. (2008). Toys to tools: Connecting student cell phones to education. Eugene, OR: ISTE.

Kolb, L. (2011). Cell phones in the classroom: A practical guide for educators. Eugene, OR: ISTE.

Kolowich, S. (2010, December 22). Apple of their eye? Inside Higher Ed. Retrieved from http://www.insidehighered.com/news/2010/12/22/college_students_test_drive_the_apple_ipad

Kress, G., \& Pachler, N. (2007). Thinking about the ' $m$ ' in m-learning. In Pachler, N. (Ed.), Mobile learning: Towards a research agenda (pp. 7-32). London: Institute of Education, London. Retrieved from http://www.wlecentre.ac.uk/cms/files/occasionalpapers/mobilelearning_pachler_2007.pdf

Kukulska-Hulme, A., \& de los Arcos, B. (2011). Researching emergent practice among mobile language learners. In $10^{\text {th }}$ World Conference on Mobile and Contextual Learning, 18-21 October 2011, Beijing, 
China: mLearn2011 Conference Proceedings (pp. 74-77). Beijing: Beijing Normal University. Retrieved from http://mlearn.bnu.edu.cn/source/Conference_Procedings.pdf

Kukulska-Hulme, A., Sharples, M., Milrad, M., Arnedillo-Sánchez, I., \& Vavoula, G. (2009). Innovation in mobile learning: A European perspective. International Journal of Mobile and Blended Learning, $1(1), 13-35$.

Leone, S. \& Leo, T. (2011). The synergy of paper-based and digital material for ubiquitous foreign language learners. Knowledge Management \& E-Learning, 3(3), 319-341. Retrieved from http://www.kmel-journal.org/ojs/index.php/online-publication/article/viewFile/123/101

Looi, C.-K., Seow, P., Zhang, B., So, H.-J., Chen, W., \& Wong, L.-H. (2010). Leveraging mobile technology for sustainable seamless learning: A research agenda. British Journal of Educational Technology, 41(2), 154-169.

Macgibbon, A., \& Tarica, E. (2012, May 28). BYO: Next wave in the eRevolution. The Age. Retrieved from http://www.theage.com.au/national/education/byo--next-wave-in-the-erevolution-201205261zayg.html

MacKinnon, R. (2012). Consent of the networked: The worldwide struggle for internet freedom. New York: Basic Books.

McCaffrey, M. (2011, February 8). Why mobile is a must. THE Journal. Retrieved from http://thejournal.com/articles/2011/02/08/why-mobile-is-a-must.aspx

Melhuish, K., \& Falloon, G. (2010). Looking to the future: M-learning with the iPad. Computers in New Zealand Schools: Learning, Leading, Technology, 22(3). Retrieved from http://education2x.otago.ac.nz/cinzs/mod/resource/view.php?id=114

Motteram, G., \& Ioannou-Georgiou, S. (2007). Are teachers fit for web 6.0? Paper presented at New and Emerging Technologies in ELT [English Language Teaching], Loyola College, Chennai, India, 3-5 Aug.

Murray, O. T., \& Olcese, N. R. (2011). Teaching and learning with iPads, ready or not? TechTrends, $55(6), 42-48$.

Naismith, L., Lonsdale, P., Vavoula, G., \& Sharples, M. (2004). Report 11: Literature review in mobile technologies and learning. Bristol: Futurelab. Retrieved from http://www2.futurelab.org.uk/resources/documents/lit_reviews/Mobile_Review.pdf

Nielsen, L., \& Webb, W. (2011). Teaching generation text: Using cell phones to enhance learning. San Francisco, CA: Jossey-Bass.

Oakley, G., Pegrum, M., \& Johnston, S. (in press). Introducing e-portfolios to pre-service teachers as tools for reflection and growth: Lessons learnt. Asia-Pacific Journal of Teacher Education.

Pachler, N., Bachmair, B., \& Cook, J. (2010). Mobile learning: Structures, agency, practices. New York: Springer.

Parry, D. (2011). Mobile perspectives: On teaching. Mobile literacy. EDUCAUSE Review, 46(2). Retrieved from http://net.educause.edu/ir/library/pdf/ERM1120.pdf

Pegrum, M. (2009). From blogs to bombs: The future of digital technologies in education. Perth: UWA Publishing.

Pegrum, M. (2010). 'I link, therefore I am': Network literacy as a core digital literacy. E-learning and Digital Media, 7(4), 346-354.

Pegrum, M., Howitt, C., \& Striepe, M. (2012). Learning to take the tablet: How pre-service teachers use iPads to facilitate their learning. Manuscript submitted for publication.

Redington Bennett, K. (2011/12, December - January). Less than a class set. Learning \& Leading with Technology, 39(4), 22-25. Retrieved from http://www.learningandleadingdigital.com/learning_leading/20111201\#pg24

Richardson, W., \& Mancabelli, R. (2011). Personal learning networks: Using the power of connections to transform education. Bloomington, IN: Solution Tree Press. 
Robb, T. N. (2006). Helping teachers to help themselves. In P. Hubbard \& M. Levy (Eds.), Teacher education in CALL (pp. 334-347). Amsterdam: John Benjamins.

Seppälä, P., \& Alamäki, H. (2003). Mobile learning in teacher training. Journal of Computer Assisted Learning, 19, 330-335.

Sharples, M., Taylor, J., \& Vavoula, G. (2010). A theory of learning for the mobile age: Learning through conversation and exploration across contexts. In B. Bachmair (Ed.), Medienbildung in neuen Kulturräumen: Die deutschsprachige und britische Diskussion (pp.87-99). Wiesbaden: VS Verlag für Sozialwissenschaften.

Traxler, J. (2010). Will student devices deliver innovation, inclusion, and transformation? Journal of the Research Center for Educational Technology, 6(1), 3-15.

Wansink, K., Budde, P., Baker, L., Bibolini, L., Evans, P., Hulme-Jones, L., Kwon, P., Lancaster, H., Lange, P., \& McNamara, S. (2011) Global mobile communications - Insights into worldwide developments. Retrieved from http://www.budde.com.au/Research/Global-Mobile-CommunicationsInsights-into-Worldwide-Developments.html

Watters, A. (2011, March 2). Will the iPad 2 make the grade for classroom usage? $R W W$. Retrieved from http://www.readwriteweb.com/archives/will_the_ipad_2_make_the_grade_for_classroom_usage.php

Zittrain, J. (2008). The future of the internet - And how to stop it. London: Allen Lane.

Zittrain, J. (2010, February 3). A fight over freedom at Apple's core. Financial Times. Retrieved from http://www.ft.com/intl/cms/s/2/fcabc720-10fb-11df-9a9e-00144feab49a.html

Corresponding author: Mark Pegrum, mark.pegrum@uwa.edu.au

Australasian Journal of Educational Technology (C) 2013.

Please cite as: Pegrum, M., Oakley, G., \& Faulkner, R. (2013). Schools going mobile: A study of the adoption of mobile handheld technologies in Western Australian independent schools. Australasian Journal of Educational Technology. 29(1), 66-81. 